\title{
PENGARUH KUALITAS PELAYANAN DAN CITRA PERUSAHAAN TERHADAP LOYALITAS PELANGGAN TIKI (TITIPAN KILAT) CABANG PADANG
}

\author{
Firma Tri Yulianda, Aminar Sutra Dewi \\ Sekolah Tinggi Ilmu Ekonomi KBP \\ firmatriyulianda@gmail.com
}

\begin{abstract}
Still low customer rating will be the quality of service company TIKI (express flash) is very loyal to the services provided by the company to its customers. This study purposes to test the effect of the the quality of service (reliability, responsiveness, assurance, emphaty), and corporate image variables to customer loyalty variables at TIKI branch of Padang. Methods of data collection were done through questionnaire distribution with a sample of 96 respondents. This type of research is descriptive quantitative research. The data analysis technique used is multiple linear regression. Based on the results of data processing, it can be seen that tangibles have positive and significant influence with customer loyalty, reliability has negative and insignificant effect with customer loyalty, responsiveness has negative and insignificant effect with customer loyalty, assurance has negative and insignificant effect with customer loyalty, emphaty has positive and insignificant effect with customer loyalty, image companies have a positive and significant impact with customer loyalty.
\end{abstract}

Keywords: tangibles, reliability, responsiveness, assurance, emphaty, image companies, customer loyalty

\section{PENDAHULUAN}

Perusahaan TIKI (titipan kilat) Cabang Padang merupakan suatu perusahaan yang bergerak pada bidang jasa, yaitu jasa pengiriman barang khususnya bagi masyarakat yang ada di Kota Padang. Satu satunya faktor penentu dari eksistensi perusahaan dalam memenangkan persaingan adalah kualitas pelayanan dan citra perusahaan. Menurut Haryanto (2013) kualitas pelayanan adalah model yang menggambarkan kondisi pelanggan dalam membentuk harapan akan layanan dari pengalaman masa lalu, promosi dari mulut kemulut, dan iklan dengan menbandingkan pelayanan yang mereka harapkan dengan apa yang mereka terima/rasakan. Loyalitas pelanggan dapat dilihat dari perilaku pembelian berulang kepada sebuah penyedia jasa, mempunyai sikap yang positif terhadap perusahaan tersebut, dan mempertimbangkan hanya akan menggunakan perusahaan tersebut ketika kebutuhan akan jasa tersebut muncul. Secara umum, loyalitas sering diartikan sebagai pembelian ulang yang terus menerus pada barang atau jasa yang sama (Indriani, 2015). 
Menurut Utami (1900) tangibles berkenaan dengan penampilan fisik fasilitas pelayanan, peralatan/perlengkapan, sumber daya manusia dan materi komunikasi perusahaan berkaitan secara langsung dengan indikator-indikator loyalitas pelanggan. Utami (1900) menyatakan bahwa secara parsial atau individu variabel tangibles berpengaruh positif dan signifikan terhadap loyalitas pelanggan. Hal ini berarti semakin baik tangibles berupa kebersihan toko dan kerapihan susunan barang, kerapihan penampilan karyawan seperti pakaian dan rambut yang terikat rapi dan kemutakhiran sarana (modern) dan prasarana seperti adanya fasilitas wifi dan parkiran yang luasmaka akan semakin meningkat loyalitas pelanggan pada Toko Tita Lubuk Buaya Padang. Hasil penelitian ini konsisten dengan penelitian yang dilakukan oleh Saryanti, Poniman, \& Marsono (2011) mereka menyatakan bahwa tangibles berpengaruh signifikan terhadap loyalitas nasabah BKK Pasar Kliwon Surakarta, maka hipotesis yang menyatakan tangibles berpengaruh signifikan terhadap loyalitas nasabah di BKK Pasar Kliwon Surakarta. Namun berbeda dengan penelitian yang dilakukan oleh Arief dan Elvira (2017) mereka menyatakan bahwa bukti fisik secara parsial tidak berpengaruh signifikan terhadap loyalitas pelanggan. Dengan demikian diduga hipotesis 1 yaitu tangibles berpengaruh positif dan signifikan terhadap loyalitas pelanggan TIKI (titipan kilat) Cabang Padang.

Menurut Utami (1900) indikator dari reliability terdiri dari konsistensi kerja (performance) dan sifat terpecaya (dependability) yang positif berpengaruh langsung dengan dimensi loyalitas pelanggan yaitu menyatakan hal yang positif (say positif things) memberikan rekomendasi kepada orang lain (recommend friend) dan melakukan pembelian terus menerus (continue purchasing). Utami (1900) menyatakan bahwa secara parsial atau individu variabel reliability berpengaruh positif dan signifikan terhadap loyalitas pelanggan, hal ini berarti semakin meningkat reliability berupa memberikan jasa pelayanan secara baik dari awal hingga akhir seperti kehandalan dan keramahan karyawan, keakuran struk pembelian seperti pelanggan selalu mendapatkan struk belanja sesuai dengan barang-barang yang dibeli pelanggan dan harga yang bayar pelanggan sesuai yang tertera di barang dan struk belanja maka akan semakin meningkat loyalitas pelanggan pada Toko Tita Lubuk Buaya Padang. Hasil penelitian ini konsisten dengan penelitian yang dilakukan oleh Saryanti et al (2011) mereka menyatakan bahwa reliability berpengaruh signifikan terhadap loyalitas nasabah BKK Pasar KliwonSurakarta, maka hipotesis yang menyatakan reliability berpengaruh signifikan terhadap loyalitas nasabah di BKK Pasar Kliwon Surakarta. Namun berbeda dengan penelitian yang dilakukan oleh Nuari, Irvan (2013) menyimpulkan bahwa reliability berpengaruh negatif dan tidak signifikan terhadap loyalitas. Dengan demikian diduga hipotesis 2 yaitu reliability berpengaruh positif dan signifikan terhadap loyalitas pelanggan TIKI (titipan kilat) Cabang Padang.

Menurut Utami (1900) responsiveness yaitu kesediaan dan kesigapan para karyawan untuk membantu dan melayani pelanggan dengan segera, berpengaruh secara langsung dan positif terhadap loyalitas pelanggan. Karena memberikan nilai plus berupa motivasi khusus bagi para pelanggan untuk menjalin ikatan relasi saling menguntungkan dalam jangka panjang.Ikatan 
inilah yang menjadikan pelanggan menjadi loyal. Utami (1900) menyatakan bahwa secara parsial atau individu variabel responsiveness berpengaruh positif dan signifikan terhadap loyalitas pelanggan. Hal ini berarti semakin tinggi responsiveness berupakesediaan pemilik dan karyawan dalam memberikan layanan secara cepat kepada pelanggan tanpa harus diminta oleh pelanggan dan tidak adanya karyawan yang mengobrol sesama karyawan dan cuek kepada pelanggan, kesediaan pemilik dan karyawan dalam membantu kesulitan pelanggan dengan secara cepat tanpa membuat pelanggan harus menunggu dan keluangan waktu karyawan dan pemilik untuk menanggapi permintaan pelanggan dengan cepat tanpa mementingkan pekerjaannya yang lain yang berarti karyawan harus menghentikan pekerjaannya yang tidak berhubungan dengan pelayanan terhadap pelanggan maka akan semakin meningkat loyalitas pelanggan pada Toko Tita Lubuk Buaya Padang. Hasil penelitian ini konsisten dengan penelitian yang dilakukan oleh Saryanti et al (2011) mereka menyatakan bahwa responsiveness berpengaruh signifikan terhadap loyalitas nasabah BKK Pasar Kliwon Surakarta, maka hipotesis yang menyatakan responsiveness berpengaruh signifikan terhadap loyalitas nasabah di BKK Pasar Kliwon Surakarta. Namun berbeda dengan penelitian yang dilakukan oleh Nuari, Irvan (2013) menyimpulkan bahwa responsiveness berpengaruh negatif dan tidak signifikan terhadap loyalitas. Dengan demikian diduga hipotesis 3 yaitu responsiveness berpengaruh positif dan signifikan terhadap loyalitas pelanggan TIKI (titipan kilat) Cabang Padang.

Menurut Utami (1900) assurance berkenaan dengan pengetahuan personality karyawan serta kemampuan mereka dalam menumbuhkan rasa percaya diri (trust) dan keyakinan pelanggan (confidence), memberikan kontribusi positif terhadap terwujudnya loyalitas pelanggan. Karena pelanggan merasa dimengerti dan akhirnya merasa nyaman sehingga membuat pelanggan tersebut menjadi loyal. Utami (1900) menyatakan bahwa secara parsial atau individu variabel assurance berpengaruh positif dan signifikan terhadap loyalitas pelanggan. Hal ini berarti semakin meningkat assurance berupa reputasi toko yang terjamin seperti tidak pernah mencurangi pelanggan karena sekali mencurangi pelanggan maka nama baik toko pun akan rusak dan informasi akan mudah tersebar dari mulut ke mulut, kompetensi dan kemampuan karyawan dalam melayani yang berarti karyawan harus mengetahui barang-barang yang ada di toko serta letaknya karena ini akan mempermudah karyawan apabila ada pelanggan yang bertanya dan keramahan karyawan dan pemilik dalam memberikan layanan maka akan semakin meningkat loyalitas pelanggan pada Toko Tita Lubuk Buaya Padang. Hasil penelitian ini konsisten dengan penelitian yang dilakukan oleh Saryanti et al (2011) mereka menyatakan bahwa assurance berpengaruh signifikan terhadap loyalitas nasabah BKK Pasar Kliwon Surakarta, maka hipotesis yang menyatakan assurance berpengaruh signifikan terhadap loyalitas nasabah di BKK Pasar Kliwon Surakarta. Namun berbeda dengan penelitian yang dilakukan oleh Nuari, Irvan (2013) menyimpulkan bahwa assurance berpengaruh positif dan tidak signifikan terhadap loyalitas. Ketut Gunawan \& S. Pantja Djati (2011) menyimpulkan bahwa assurance tidak berpengaruh 
terhadap loyalitas pasien. Dengan demikian diduga hipotesis ke 4 yaitu assurance berpengaruh positif dan signifikan terhadap loyalitas pelanggan TIKI (titipan kilat) Cabang Padang.

Menurut Utami (1900) emphaty berarti perusahaan memahami masalah pelanggannya dan bertindak demi kepentingan pelanggan, berpengaruh secara positif dimensi loyalitas pelanggan yaitu tetap memilih merek tersebut, merekomendasikannya kepada orang lain dan melakukan pembelian secara ulang. Utami (1900) menyatakan bahwa secara parsial atau individu variabel emphaty berpengaruh positif dan signifikan terhadap loyalitas pelanggan. Hal ini berarti semakin tinggi emphaty berupa perhatian secara personal oleh pemilik dan karyawan seperti karyawan melayani dengan sepenuh hati dan penuh senyuman apabila pelanggan bertanya tentang suatu produk yang dibutuhkan pelanggan serta menolong pelanggan tanpa harus diminta oleh pelanggan, toko mudah diakses seperti jarak yang dekat dan mudahnya angkutan umum untuk menuju ketoko dan memperhatikan kebutuhan pelanggan dengan sungguh-sungguh maka akan semakin meningkat loyalitas pelanggan pada Toko Tita Lubuk Buaya Padang. Hasil penelitian ini konsisten dengan penelitian yang dilakukan oleh Saryanti et al (2011) mereka menyatakan bahwa emphaty berpengaruh signifikan terhadap loyalitas nasabah BKK Pasar Kliwon Surakarta, maka hipotesis yang menyatakan emphaty berpengaruh signifikan terhadap loyalitas nasabah di BKK Pasar Kliwon Surakarta. Namun berbeda dengan penelitian yang dilakukan oleh Nuari, Irvan (2013) menyimpulkan bahwa emphaty berpengaruh negatif dan tidak signifikan terhadap loyalitas. Marcell \& Adiwijaya (2017) mereka menyimpulkan bahwa emphaty tidak berpengaruh signifikan terhadap loyalitas pelanggan jasa percetakan. Dengan demikian diduga hipotesis ke 5 emphaty berpengaruh positif dan signifikan terhadap loyalitas pelanggan TIKI (titipan kilat) Cabang Padang.

Suatu perusahaan akan dilihat melalui citranya baik citra itu negatif atau positif. Citra yang positif akan memberikan arti yang baik terhadap produk perusahaan tersebut dan seterusnya dapat meningkat-kan jumlah penjualan. Citra yang positif juga membantu meningkatkan minat pelanggan pada promosi merek dimasa yang akan datang, dan memperkuat posisi dalam berbagai kegiatan pemasaran pesaing. Kepuasan pelanggan mempunyai hubungan positif yang kuat dengan loyalitas pelanggan.Kepuasan pelanggan merupakan faktor utama ataumempunyai pengaruh yang paling kuat terhadap loyalitas pelanggan. Perusahaan perlu emonitor dan meningkatkan kepuasan pelanggannya karena makin tinggi kepuasan pelanggan, berarti makin besar pula kemungkinan pelanggan tetap setia (Natalia, 2010). Suratno et al (2016) mereka menyatakan bahwa terdapat pengaruh positif dan signifikan antara citra perusahaan terhadap loyalitas pelanggan. Artinya semakin tinggi citra perusahaan maka loyalitas pelanggan akan meningkat. Hasil penelitian ini konsisten dengan penelitian yang dilakukan oleh Purba (2017) dimana Citra Perusahaan bepengaruh positif dan signifikan terhadap loyalitas pelanggan. Dengan demikian diduga hipotesis 6 yaitu citra perusahaan berpengaruh positif dan signifikan terhadap loyalitas pelanggan. 
Berdasarkan wawancara kepada 10 orang beberapa pelanggan yang telah menggunakan jasa pelayanan TIKI (Titipan Kilat) lebih dari 2 kali, dimana wawancara dilakukan pada tanggal 14 oktober 2016 bahwa masih rendahnya penilaian pelanggan akan kualitas pelayanan perusahaan TIKI (titipan kilat) yang menyebabkan sedikitnya pelanggan loyal terhadap pelayanan yang diberikan oleh pihak perusahaan kepada pelanggannya. Hal ini disebabkan masih adanya pengiriman yang tidak tepat waktu, lamanya prosedur akan transaksi dari pihak perusahaan dalam melayani pelanggan yang datang,dan masih kurang baiknya citra perusahaan dikarenakan pelayanan yang masih jauh dari harapan pelanggan. Berdasarkan hal tersebut sudah dapat diketahui bahwa belum sepenuhnya ada pelanggan yang benar-benar dikatakan loyal karena pelanggan tidak selalu melakukan pengiriman barang dengan menggunakan jasa TIKI Cabang Padang seperti POS, JNE, dan J\&T.

\section{METODE PENELITIAN}

Jenis penelitian ini adalah penelitian kuantitatif. Objek penelitian ini adalah semua pelanggan atau orang yang pernah menggunakan jasa pengiriman dengan TIKI (titipan kilat) Cabang Padang. Populasi yang digunakan dalam penelitian ini adalah semua pelanggan atau orang yang pernah menggunakan jasa pengiriman dengan TIKI (titipan kilat) Cabang Padang. Teknik pengambilan sampel yang digunakan adalah dengan metode kebetulan atau accidental sampling, maka jumlah sampel sebanyak 96 orang.

\section{Definisi Operasional Variabel}

\section{Tabel 1}

Definisi Operasional Variabel

\begin{tabular}{|c|c|c|c|c|}
\hline No & Variabel & Definisi & Indikator & Dimensi \\
\hline 1 & $\begin{array}{l}\text { Loyalitas } \\
\text { Pelanggan }\end{array}$ & $\begin{array}{l}\text { Bukti emosi yang } \\
\text { mentransformasikan } \\
\text { perilaku pembelian } \\
\text { berulang menjadi suatu } \\
\text { hubungan. }\end{array}$ & $\begin{array}{l}\text { 1. Repeat } \\
\text { Purchase } \\
\text { 2. Retention } \\
\text { 3. Referalls }\end{array}$ & \\
\hline 2 & $\begin{array}{l}\text { Kualitas } \\
\text { Pelayanan }\end{array}$ & $\begin{array}{l}\text { Kualitas pelayanan } \\
\text { berkaitan erat dengan } \\
\text { pelanggan, kualitas } \\
\text { pelayanan memberikan } \\
\text { dorongan khusus bagi } \\
\text { para pelanggan untuk } \\
\text { menjalin ikatan relasi, } \\
\text { saling menguntungkan } \\
\text { dalam jangka panjang } \\
\text { dengan perusahaan }\end{array}$ & & $\begin{array}{l}\text { 1. } \text { Tangibles } \\
\text { 2. Reliability } \\
\text { 3. Responsiveness } \\
\text { 4. Assurance } \\
\text { 5. Emphaty }\end{array}$ \\
\hline 3 & $\begin{array}{l}\text { Citra } \\
\text { Perusahaan }\end{array}$ & $\begin{array}{l}\text { Persepsi masyarakat } \\
\text { atau konsumen terhadap } \\
\text { perusahaan atau produk } \\
\text { yang dihasilkan oleh } \\
\text { suatu perusahaan }\end{array}$ & $\begin{array}{l}\text { 1. Kesan } \\
\text { 2. Kepercayaan } \\
\text { 3. Sikap }\end{array}$ & \\
\hline
\end{tabular}

Sumber : Kotler \& Keller (2006); Tjiptono (2005) ; Sutojo (2004) 


\section{Teknik Analisis Data}

Teknik analisis data yang digunakan dalam penelitian ini adalah :

1. Uji Validitas

Uji validitas menurut Nugroho (2005:67) digunakan untuk mengetahui kelayakan butir-butir dalam suatu daftar (konstruk) pertanyaan dalam mendefinisikan variabel.

2. Uji Reliabilitas

Uji reliabilitas menurut Nugroho (2005:72) merupakan ukuran suatu kestabilan dan konsistensi responden dalam menjawab hal yang berkaitan dengan konstruk-konstruk pertanyaan yang merupakan dimensi suatu variabel dan disusun dalam suatu bentuk kuesioner.

3. Analisis Deskriptif

Analisis deskriptif adalah penyajian data secara numerik untuk mengetahui nilai rata-rata, minimal, maksimal dan standar deviasi dari variabelvariabel yang diteliti.

4. Uji Asumsi Klasik

Uji asumsi klasik digunakan untuk menguji apakah model regresi benarbenar menunjukkan hubungan yang signifikan dan representative. Ada tiga pengujian dalam uji asumsi klasik, yaitu:

a. Uji Normalitas

b. Uji Multikolinearitas

c. Uji Heteroskedastisitas

5. Analisis Regresi Linear Berganda

Persamaan regresi linear berganda sebagai berikut:

$$
\mathrm{Y}=\mathrm{a}+\mathrm{b} 1 \mathrm{X} 1+\mathrm{b} 2 \mathrm{X} 2+\mathrm{b3X3}+\mathrm{b} 4 \mathrm{X} 4+\mathrm{b5X5}+\mathrm{b} 6 \mathrm{X6}+\mathrm{e}
$$

Berdasarkan model ini, dijelaskan bahwa, $\mathrm{Y}=$ Loyalitas, $\mathrm{a}=$ Konstanta, $\mathrm{X} 1$ $=$ Tangibles, $\mathrm{X} 2=$ reliability, $\mathrm{X} 3=$ responsiveness, $\mathrm{X} 4=$ assurance, $\mathrm{X} 5=$ emphaty, $\mathrm{X} 6=$ Citra Perusahaan, $\mathrm{b} 1=$ Koefesien regresi tangibles, $\mathrm{b} 2=$ Koefesien regresi reliability, b3=Koefesien regresi responsiveness, b4 =Koefesien regresi assurance, b5 =Koefesien regresi emphaty, b6 =Koefesien regresi Citra Perusahaan. 


\begin{tabular}{|c|c|c|c|}
\hline \multicolumn{4}{|c|}{$\begin{array}{l}\text { IASIL DAN PEMBAHASAN } \\
\text { Analisis Deskriptif } \\
\text { Responden dalam penelitian ini dapat dikelompokkan berdasarkan } \\
\text { umur, jenis kelamin, dan rata-rata pendapatan perbulan } \\
\text { Tabel } 2 \\
\text { Karakteristik Responden Berdasarkan Umur, Jenis Kelamin, Dan Rata- } \\
\text { Rata Pendapatan Perbulan. }\end{array}$} \\
\hline NO & KELOMPOK & $\begin{array}{l}\text { Jumlah } \\
\text { (Orang) }\end{array}$ & Persentase $(\%)$ \\
\hline \multirow{5}{*}{1} & Umur & & \\
\hline & $20-29$ & 50 & 52,1 \\
\hline & $30-39$ & 17 & 17,7 \\
\hline & $40-49$ & 13 & 13,5 \\
\hline & $>50$ & 16 & 16,7 \\
\hline \multirow{3}{*}{2} & Jenis Kelamin & & \\
\hline & Laki-laki & 61 & 63,5 \\
\hline & Perempuan & 35 & 36,5 \\
\hline \multirow{5}{*}{3} & Pendapatan & & \\
\hline & $<$ Rp.1000.000 & 27 & 28,1 \\
\hline & Rp.1000.000-Rp.2.000.000 & 33 & 34,4 \\
\hline & Rp.2000.000-Rp.3.000.000 & 23 & 24,0 \\
\hline & > Rp.3.000.000 & 13 & 13,5 \\
\hline
\end{tabular}

Data penelitian berdasarkan tabel di atas menunjukan bahwa responden berdasarkan umur yang paling banyak yaitu 20-29 tahun yaitu sebayak 50 orang atau 52,1 \%, Sedangkan responden yang paling sedikit berumur 40-49 tahun yaitu sebanyak 13 orang atau 13,5\%. Berdasarkan jenis kelamin pada tabel di atas menunjukkan bahwa jumlah responden yang paling banyak adalah responden lakilaki yaitu sebanyak 61 orang atau $63,5 \%$ dan sebanyak 35 orang atau 36,5\% lagi adalah responden perempuan. Jadi dapat disimpulkan bahwa jumlah pelanggan jenis kelamin laki-laki pada jasa pengiriman TIKI (titipan kilat) Cabang Padang lebih banyak dari pada pelanggan berjenis kelamin perempuan. Berdasarkan pendapatan/bulan paling banyak adalah 33 orang responden atau 34,4 \% yang memiliki pendapatan perbulan antara Rp 1.000.000 sampai dengan Rp 2.000.000. Sedangkan responden yang paling sedikit adalah yang memiliki pendapatan perbulan di atas Rp 3.000.000 yaitu hanya 13 orang responden atau 13,5\%. 
Uji Validitas

Tabel 3

Hasil Uji Validitas 2 Kualitas Pelayanan

\begin{tabular}{cccc}
\hline Variabel & $\begin{array}{c}\text { No } \\
\text { Butir }\end{array}$ & $\begin{array}{c}\text { Corrected Item- } \\
\text { Total Correlation }\end{array}$ & Keterangan \\
\hline 1 & 0.749 & Valid \\
2 & 0.698 & Valid \\
3 & 0.799 & Valid \\
4 & 0.411 & Valid \\
5 & 0.658 & Valid \\
Kualitas Pelayanan & 6 & 0.524 & Valid \\
& 7 & 0.663 & Valid \\
& 8 & 0.411 & Valid \\
& 9 & 0.749 & Valid \\
& 10 & 0.698 & Valid \\
11 & 0.799 & Valid \\
Loyalitas Pelanggan & 12 & 0.411 & Valid \\
& 13 & 0.658 & Valid \\
& 14 & 0.524 & Valid \\
& 15 & 0.663 & Valid \\
& 16 & 0.411 & Valid \\
& 17 & 0.458 & Valid \\
& 1 & 0.546 & Valid \\
& 2 & 0.600 & Valid \\
& 3 & 0.776 & Valid \\
& 1 & 0.690 & Valid \\
& 2 & 0.603 & Valid \\
& 0.642 & Valid \\
& 0.678 & Valid \\
\hline
\end{tabular}

Berdasarkan hasil tabel diatas dapat disimpulkan bahwa semua butir pertanyaan dalam kuesioner ini valid. 


\section{Uji Reliabilitas}

Tabel 3

Hasil Uji Reliabilitas 2 Kualitas Pelayanan

\begin{tabular}{ccccc}
\hline \multirow{2}{*}{ Variabel } & \multicolumn{2}{c}{$\mathbf{N = 3 0}$} & Rule & \\
\cline { 2 - 4 } & $\begin{array}{c}\text { Jumlah } \\
\text { butir } \\
\text { permyataan }\end{array}$ & $\begin{array}{c}\text { Cronbach's } \\
\text { Alpha }\end{array}$ & $\begin{array}{c}\text { of } \\
\text { thumb }\end{array}$ & Keputusan \\
\hline Kualitas Pelayanan & 17 Butir & 0,914 & 0,6 & Reliable \\
Citra Perusahaan & 3 Butir & 0,79 & 0,6 & Reliable \\
Loyalitas Pelanggan & 4 Butir & 0,818 & 0,6 & Reliable \\
\hline Berdasarkan hasil tabel diatas dapat & disimpulkan & bahwa & semua butir \\
pertanyaan dalam kuesioner ini reliabel. & & &
\end{tabular}

Uji Asumsi Klasik

Uji Normalitas

Tabel 4

Hasil Uji Normalitas

\begin{tabular}{llr}
\hline \multicolumn{2}{c}{ One-Sample Kolmogorov-Smirnov } & Test \\
\hline \multicolumn{3}{c}{ Standardized Residual } \\
\hline $\mathrm{N}$ & & 96 \\
Normal & Mean & 0 \\
Parameters & ${ }^{2}$ & Std. Deviation \\
Most & Absolute & 0.98941769 \\
Extreme & Positive & 0.071 \\
Differences & Negative & 0.045 \\
Kolmogorov-Smirnov Z & -0.071 \\
Asymp. Sig. (2-tailed) & 0.698 \\
\hline \multicolumn{2}{c}{ Berdasarkan hasil uji normalitas diatas diketahui bahwa nilai Asymp. Sig. }
\end{tabular}

(2-tailed) untuk variabel Kualitas Pelayanan $\left(\mathrm{X}_{1}\right)$, variabel Citra Pelayanan $\left(\mathrm{X}_{2}\right)$ variabel Loyalitas Pelanggan (Y) sebesar 0,714>0,05. maka disimpulkan bahwa seluruh data variabel dalam penelitian ini (kualitas pelayanan, citra perusahaan, dan loyalitas pelanggan) telah terdistribusi secara normal.

Uji Multikolinearitas

Tabel 5

Hasil Uji Multikolonieritas

\begin{tabular}{ccccc}
\hline No & Variabel & Tolerance & VIF & Keterangan \\
\hline 1 & Tangibles & 0.174 & 5.758 & Tidak Multikolonieritas \\
2 & Reliability & 0.384 & 2.601 & Tidak Multikolonieritas \\
3 & Responsiveness & 0.375 & 2.663 & Tidak Multikolonieritas \\
4 & Assurance & 0.254 & 3.932 & Tidak Multikolonieritas \\
5 & Emphaty & 0.479 & 2.086 & Tidak Multikolonieritas \\
6 & Citra Perusahaan & 0.758 & 1.32 & Tidak Multikolonieritas \\
\hline
\end{tabular}


Berdasarkan tabel diatas menunjukkan bahwa semua variabel independen (kualitas pelayanan, citra perusahaan) mempunyai nilai tolerance besar dari 0,1 dan nilai VIF yang cukup kecil, dimana semuanya berada dibawah 10. maka dapat disimpulkan bahwa data variabel kualitas pelayanan dengan citra perusahaan tidak terjadi hubungan multikolinearitas.

\section{Uji Heteroskedastisitas}

Tabel 6

Hasil Uji Heteroskedastisitas

\begin{tabular}{clccc}
\hline No & \multicolumn{1}{c}{ Variabel } & Sig & Alpha & Keterangan \\
\hline 1 & Tangibless & 0.599 & 0,05 & Tidak Heteroskedastisitas \\
2 & Reliability & 0.130 & 0,05 & Tidak Heteroskedastisitas \\
3 & Responsiveness & 0.212 & 0,05 & Tidak Heteroskedastisitas \\
4 & Assurance & 0.768 & 0,05 & Tidak Heteroskedastisitas \\
5 & Emphaty & 0.060 & 0,05 & Tidak Heteroskedastisitas \\
6 & Citra Perusahaan & 0.111 & 0,05 & Tidak Heteroskedastisitas \\
\hline
\end{tabular}

Berdasarkan hasil uji heteroskedastisitas diatas, semua variabel penelitian ini tidak terjadi heteroskedastisitas. karena nilai signifikan dari semua variabel lebih besar dari tingkat signifikan yang digunakan $(\alpha=0,05)$.

Analis is Regresi Linear Berganda

Tabel 7

Hasil Uji Analisis Regresi Linear Berganda

\begin{tabular}{|c|c|c|c|c|c|}
\hline \multicolumn{6}{|c|}{ Coefficients $^{\mathrm{a}}$} \\
\hline \multirow{2}{*}{ Model } & \multicolumn{2}{|c|}{$\begin{array}{l}\text { Unstandardized } \\
\text { Coefficients }\end{array}$} & \multirow{2}{*}{$\begin{array}{c}\text { Standardized } \\
\text { Coefficients } \\
\text { Beta }\end{array}$} & \multirow{2}{*}{$\mathrm{T}$} & \multirow{2}{*}{ Sig. } \\
\hline & B & $\begin{array}{l}\text { Std. } \\
\text { Error }\end{array}$ & & & \\
\hline (Constant) & 5.459 & 2.408 & & 2.267 & 0.026 \\
\hline Tangibless & 0.569 & 0.219 & 0.563 & 2.601 & 0.011 \\
\hline Reliability & -0.274 & 0.22 & -0.181 & 1.247 & 0.216 \\
\hline Responsiveness & -0.281 & 0.201 & -0.206 & 1.401 & 0.165 \\
\hline Assurance & -0.072 & 0.239 & -0.054 & 0.301 & 0.764 \\
\hline Emphaty & 0.497 & 0.268 & 0.241 & 1.85 & 0.068 \\
\hline $\begin{array}{l}\text { Citra } \\
\text { Perusahaan }\end{array}$ & 0.320 & 0.136 & 0.243 & 2.348 & 0.021 \\
\hline
\end{tabular}

Sumber : Data diolah, Lampiran 11

Berdasarkan tabel diatas maka dapat dilihat persamaan regresinya yaitu :

$Y=5,459+0,569 X_{1}-0,274 X_{2}-0,281 X_{3}-0,072 X_{4}+0,497 X_{5}+0,320 X_{6}+e$

Nilai konstanta sebesar 5,459 berarti bahwa nilai loyalitas pelanggan adalah sebesar 5,459 dengan asumsi variabel lain bernilai nol. Nilai konstanta 
sebesar 5,459 berarti bahwa nilai loyalitas pelanggan adalah sebesar 5,459 dengan asumsi variabel lain bernilai nol. Nilai koefisien regresi tangibles sebesar 0,569 maksudnya adalah setiap peningkatan satu satuan tangibles, maka akan mengakibatkan peningkatan nilai koefisien loyalitas pelanggan sebesar 56,9\%. Dalam hal ini faktor-faktor lain yang mempengaruhi loyalitas perusahaan dianggap tetap. Nilai koefisien regresi reliability sebesar -0,274 maksudnya adalah setiap peningkatan satu satuan reliability, maka akan mengakibatkan penurunan nilai koefisien loyalitas pelanggan sebesar 27,4\%. Dalam hal ini faktor-faktor lain yang mempengaruhi loyalitas perusahaan dianggap tetap. Nilai koefisien regresi responsiveness sebesar $-0,281$ maksudnya adalah setiap peningkatan satu satuan responsiveness, maka akan mengakibatkan penurunan nilai koefisien loyalitas pelanggan sebesar 28,1\%. Dalam hal ini faktor-faktor lain yang mempengaruhi loyalitas perusahaan dianggap tetap. Nilai koefisien regresi assurance sebesar -0,072 maksudnya adalah setiap peningkatan satu satuan assurance, maka akan mengakibatkan penurunan nilai koefisien loyalitas pelanggan sebesar 7,2 \%. Dalam hal ini faktor-faktor lain yang mempengaruhi loyalitas perusahaan dianggap tetap. Nilai koefisien regresi emphaty sebesar 0,497 maksudnya adalah setiap peningkatan satu satuan emphaty, maka akan mengakibatkan peningkatan nilai koefisien loyalitas pelanggan sebesar $49,7 \%$. Dalam hal ini faktor-faktor lain yang mempengaruhi loyalitas perusahaan dianggap tetap. Nilai koefisien regresi citra perusahaan sebesar 0,320 maksudnya adalah setiap peningkatan satu satuan citra perusahaan, maka akan mengakibatkan peningkatan nilai koefisien loyalitas pelanggan sebesar 32\%. Dalam hal ini faktor-faktor lain yang mempengaruhi loyalitas perusahaan dianggap tetap.

\section{Uji Hipotesis}

\section{Uji F}

Tabel 8

Hasil Uji F

\begin{tabular}{crrrrr}
\hline \multicolumn{7}{c}{ ANOVA $^{\mathbf{b}}$} \\
\hline \multirow{2}{*}{ Model } & $\begin{array}{c}\text { Sum of } \\
\text { Squares }\end{array}$ & Df & $\begin{array}{c}\text { Mean } \\
\text { Square }\end{array}$ & F & Sig. \\
\hline Regression & 96.533 & 6 & 16.089 & 5.689 & $.000^{\text {a }}$ \\
Residual & 251.707 & 89 & 2.828 & & \\
Total & 348.240 & 95 & & & \\
\hline
\end{tabular}

Sumber : Data diolah, Lampiran 10

Dari tabel diketahui $\mathrm{F}_{\text {hitung }} 5.689>\mathrm{F}_{\text {tabel }} 3.09$ dengan nilai Sig. $0.000<$ 0.05 maka dapat disimpulkan bahwa variabel kualitas pelayanan yang terdiri dari tangibles, reliability, responsiveness, assurance, emphaty dan citra perusahaan berpengaruh signifikan terhadap Loyalitas Pelanggan pada perusahaan TIKI (titipan kilat) cabang padang. 


\section{Uji $\mathbf{t}$}

Tabel 9

Hasil Uji T

\begin{tabular}{clrcccc}
\hline No & Variabel & t-hitung & t-tabel & Sig. & Alpha & Keterangan \\
\hline 1 & Tangibless & 2.601 & 1.98498 & 0.011 & 0,05 & Signifikan \\
2 & Reliability & -1.247 & 1.98498 & 0.216 & 0,05 & Tidak Signifikan \\
3 & Responsiveness & -1.401 & 1.98498 & 0.165 & 0,05 & Tidak Signifikan \\
4 & Assurance & -0.301 & 1.98498 & 0.764 & 0,05 & Tidak Signifikan \\
5 & Emphaty & 1.85 & 1.98498 & 0.068 & 0,05 & Tidak Signifikan \\
6 & Citra Perusahaan & 2.348 & 1.98498 & 0.021 & 0,05 & Signifikan \\
\hline
\end{tabular}

Sumber : Data diolah, Lampiran 11

1. Berdasarkan variabel tangibles diketahui $t_{\text {hitung }} 2.601>t_{\text {tabel }}$ 1.98498 dengan nilai Sig. $0.011<0.05$ sehingga Ho ditolak dan $\mathrm{Ha}$ diterima.

2. Berdasarkan variabel reliability diketahui $\mathrm{t}_{\mathrm{hitung}}-1.247<\mathrm{t}_{\text {tabel }}$ 1.98498 dengan nilai Sig. $0.216>0.05$ sehingga Ho diterima dan Ha ditolak.

3. Berdasarkan variabel responsiveness diketahui $t_{\text {hitung }}-1.401<t_{t a b e l}$ 1.98498 dengan nilai Sig. $0.165>0.05$ sehingga Ho diterima dan Ha ditolak.

4. Berdasarkan variabel assurance diketahui $t_{\text {hitung }}-0.301<\mathrm{t}_{\text {tabel }}$ 1.98498 dengan nilai Sig. $0.764>0.05$ sehingga Ho diterima dan Ha ditolak.

5. Berdasarkan variabel emphaty diketahui $t_{\text {hitung }} 1.850<t_{\text {tabel }}$ 1.98498 dengan nilai Sig. $0.068>0.05$ sehingga Ho diterima dan Ha ditolak.

6. Berdasarkan variabel citra perusahaan diketahui $t_{\text {hitung }} 2.348>t_{t a b e l}$ 1.98498 dengan nilai Sig. $0.021<0.05$ sehingga Ho ditolak dan $\mathrm{Ha}$ diterima.

Uji $\mathbf{R}^{2}$

Berdasarkan tabel di atas diperoleh angka $\mathrm{R}^{2}$ (Adjusted $\mathrm{R}$ square) sebesar 0,228 atau 22,8\%, hal ini menunjukkan bahwa persentase sumbangan variabel independen tangibles $\left(\mathrm{X}_{1}\right)$, reliability $\left(\mathrm{X}_{2}\right)$, responsiveness $\left(\mathrm{X}_{3}\right)$, assurance $\left(\mathrm{X}_{4}\right)$, emphaty $\left(\mathrm{X}_{5}\right)$ dan citra perusahaan $\left(\mathrm{X}_{6}\right)$ terhadap variabel dependen loyalitas pelanggan (Y) sebesar 0,228 atau $22,8 \%$. Sedangkan sisanya sebesar $77,2 \%$ dipengaruhi oleh variabel lain di luar penelitian ini seperti nilai pelanggan,kepuasaan pelanggan. 


\section{PEMBAHASAN}

\section{Pengaruh tangibles terhadap loyalitas pelanggan}

Berdasarkan hipotesis pertama telah diasumsikan bahwa tanggibles $\left(\mathrm{X}_{1}\right)$ berpengaruh positif dansignifikan terhadap loyalitas pelanggan TIKI (titipan kilat) Cabang Padang.Dari hasil pengolahan data dihasilkan nilai koefisien regresi untuk variabel tanggibles sebesar 0,569 bertanda positif dengan nilai Sig. $0.011<0.05$ yang berarti bahwa tanggibles mempunyai pengaruh positif dan signifikan terhadap loyalitas pelanggan TIKI (titipan kilat) Cabang Padang. Dengan demikian dapat disimpulkan hipotesis pertama diterima.

Menurut Tjiptono (2011:198). "tangibles berkenaan dengan daya tarik fasilitas fisik, perlengkapan dan material yang digunakan,serta penampilan karyawan".

Hasil penelitian ini diperkuat oleh Utami, Hayu Yolanda (2014) tentang Pengaruh tangibles, empathy, reliability, responsiveness dan assurance terhadap loyalitas pelanggan berbelanja pada toko Tita di Lubuk Buaya kota Padang menyatakan bahwa secara parsial atau individu variabel tangibles berpengaruh positif dan signifikan terhadap loyalitas pelanggan.

\section{Pengaruh reliability terhadap loyalitas pelanggan}

Berdasarkan hipotesis kedua telah diasumsikan bahwa reliability $\left(\mathrm{X}_{2}\right)$ berpengaruh negatif dan tidak signifikan terhadap loyalitas pelanggan TIKI (titipan kilat) Cabang Padang.Dari hasil pengolahan data dihasilkan nilai koefisien regresi untuk variabel reliability sebesar -0.274 bertanda negatif dengan nilai Sig. $0.216>0.05$ yang berarti bahwa reliability mempunyai pengaruh negatif dan tidak signifikan terhadap loyalitas pelanggan TIKI (titipan kilat) Cabang Padang. Dengan demikian dapat disimpulkan hipotesis kedua ditolak.

Menurut Tjiptono \& Chandra (2011:198), 'kemampuan perusahaan untuk memberikan pelayanan yang akurat sejak pertama kali tanpa membuat kesalahan apapun dan menyampaikan jasanya sesuai dengan waktu yang disepakati”.

Hasil penelitian ini diperkuat oleh Nuari, Irvan (2013) tentang Analisis Kepuasan dan Loyalitas Konsumen pada The Jungle Water Park (TJWP) menyimpulkan bahwa reliability berpengaruh negatif dan tidak signifikan terhadap loyalitas.

\section{Pengaruh responsiveness terhadap loyalitas pelanggan}

Berdasarkan hipotesis ketiga telah diasumsikan bahwa responsiveness $\left(\mathrm{X}_{3}\right)$ berpengaruh negatif dan tidak signifikan terhadap loyalitas pelanggan TIKI (titipan kilat) Cabang Padang.Dari hasil pengolahan data dihasilkan nilai koefisien regresi untuk variable responsiveness sebesar -0.281 bertanda negatif dengan nilai Sig. $0.165>0.05$ yang berarti bahwa responsiveness mempunyai pengaruh negatif dan tidak signifikan terhadap loyalitas pelanggan TIKI (titipan kilat) Cabang Padang. Dengan demikian dapat disimpulkan hipotesis ketiga ditolak.

Menurut Tjiptono (2011:198) "responsiveness yaitu kesediaan dan kemampuan para karyawan untuk membantu para pelanggan dan merespon permintaan mereka, serta menginformasikan kapan jasa akan diberikan dan kemudian memberikan jasa secara cepat".

Hasil penelitian ini diperkuat oleh Nuari, Irvan (2013) tentang Analisis Kepuasan dan Loyalitas Konsumen pada The Jungle Water Park (TJWP) 
menyimpulkan bahwa responsiveness berpengaruh negatif dan tidak signifikan terhadap loyalitas.

\section{Pengaruh assurance terhadap loyalitas pelanggan}

Berdasarkan hipotesis keempat telah diasumsikan bahwa assurance $\left(\mathrm{X}_{4}\right)$ berpengaruh negatif dan tidak signifikan terhadap loyalitas pelanggan TIKI (titipan kilat) Cabang Padang.Dari hasil pengolahan data dihasilkan nilai koefisien regresi untuk variable assurance sebesar -0.072 bertanda negatif dengan nilai Sig. $0.764>0.05$ yang berarti bahwa assurance mempunyai pengaruh negatif dan tidak signifikan terhadap loyalitas pelanggan TIKI (titipan kilat) Cabang Padang. Dengan demikian dapat disimpulkan hipotesis keempat ditolak.

Menurut Tjiptono (2011:198) "adalah assurance perilaku para karyawan mampu menumbuhkan kepercayaan pelanggan terhadap perusahaan bias menciptakan rasa aman bagi para pelanggannya".

Hasil penelitian ini diperkuat oleh Ketut Gunawan \& S. Pantja Djati (2011) tentang Kualitas Layanan dan Loyalitas Pasien (Studi pada Rumah Sakit Umum Swasta di Kota Singaraja-Bali) menyimpulkan bahwa assurance tidak berpengaruh terhadap loyalitas pasien.

\section{Pengaruh emphaty terhadap loyalitas pelanggan}

Berdasarkan hipotesis kelima telah diasumsikan bahwa empathy $\left(\mathrm{X}_{5}\right)$ berpengaruh positif dan tidak signifikan terhadap loyalitas pelanggan TIKI (titipan kilat) Cabang Padang.Dari hasil pengolahan data dihasilkan nilai koefisien regresi untuk variabel emphaty sebesar 0.497 bertanda positif dengan nilai Sig. 0.068> 0.05 yang berarti bahwa emphaty mempunyai pengaruh positif dan tidak signifikan terhadap loyalitas pelanggan TIKI (titipan kilat) Cabang Padang. Dengan demikian dapat disimpulkan hipotesis kelima ditolak.

Hasil penelitian ini diperkuat oleh. Nuari, Irvan (2013) tentang Analisis Kepuasan dan Loyalitas Konsumen pada The Jungle Water Park (TJWP) menyimpulkanbahwaemphaty berpengaruh tidak signifikan terhadap loyalitas. Marcell \& Adiwijaya (2017) mereka menyimpulkanbahwa emphaty tidak berpengaruh signifikan terhadap loyalitas pelanggan jasa percetakan.

\section{Penga ruh citra perusahaan terhadap loyalitas pelanggan}

Berdasarkan hipotesis keenam telah diasumsikan bahwa citra perusahaan $\left(\mathrm{X}_{6}\right)$ berpengaruh positif dan signifikan terhadap loyalitas pelanggan TIKI (titipan kilat) Cabang Padang.Dari hasil pengolahan data dihasilkan nilai koefisien regresi untuk variabel citra perusahaan sebesar0.320bertanda positif dengan nilai Sig. $0.021<0.05$ yang berarti bahwa citra perusahaan mempunyai pengaruh positif dan signifikan terhadap loyalitas pelanggan TIKI (titipan kilat) Cabang Padang. Dengan demikian dapat disimpulkan hipotesis keenam diterima.

Hasil penelitian ini diperkuat oleh Suratno et al (2016) tentang Pengaruh Citra Perusahaan dan Kualitas Pelayanan terhadap Loyalitas Pelanggan dengan Kepuasan Pelanggan sebagai variabel Intervening pada Pelabuhan Indonesia III Semarang mereka menyatakan bahwa terdapat pengaruh positif dan signifikan antara citra perusahaan terhadap loyalitas pelanggan. Artinya semakin tinggi citra perusahaan maka loyalitas pelanggan akan meningkat. Hasil penelitian ini konsisten dengan penelitian yang dilakukan oleh Purba (2017)tentang Pengaruh Citra Perusahaan terhadap Loyalitas Pelanggan (Studi Kasus PT. Bintang Utara 
Perwakilan Dolok Sanggul) dimana Citra Perusahaan berpengaruh positif dan signifikan terhadap Loyalitas Pelanggan.

\section{KESIMPULAN}

Dari hasil dan pembahasan yang telah dilakukan, dapat disimpulkan beberapa temuan sebagai berikut, 1)Variabel tangibles berpengaruh positif dan signifikan terhadap loyalitas pelanggan, 2)Variabel reliability berpengaruh negatif dan tidak signifikan terhadap loyalitas pelanggan, 3)Variabel responsiveness berpengaruh negatif dan tidak signifikan terhadap loyalitas pelanggan, 4)Variabel assurance berpengaruh negatif dan tidak signifikan terhadap loyalitas pelanggan, 5)Variabel emphaty berpengaruh positif dan tidak signifikan terhadap loyalitas pelanggan, 6)Variabel citra perusahaan berpengaruh positif dan signifikan terhadap loyalitas pelanggan.

Dalam melakukan penelitian banyak keterbatasan yang penulis temukan, bagi peneliti selanjutnya diharapkan 1)Dapat menambahkan dengan memperbanyak jumlah obsevasi agar memperoleh hasil yang lebih akurat misalnya sampel diperbanyak, unit analisis dan sampel yang berbeda, 2)Dapat menambahkan variabel independen lainnya atau menambahkan variabel moderating, 3)Dapat menggunakan metode penelitian yang berbeda seperti metode wawancara langsung kepada responden untuk memperoleh data yang lebih berkualitas.

\section{UCAPAN TERIMAKASIH}

1. Bapak Febryandhie Ananda, SE, M.Si selaku ketua STIE "KBP" Padang.

2. Ibu Aminar Sutra Dewi, SE, Msi selaku Pembimbing yang telah bersedia meluangkan waktu membimbing penulis dengan penuh perhatian, memberikan masukan serta arahan, terlebih dalam proses penyusunan skripsi ini sehingga penulis mampu menyelesaikan skripsi ini dengan baik.

3. Ibu Febsri Susanti, SE, M.Si selaku ketua program studi Manajemen.

4. Ibu Lidya Martha SE.MM selaku penasehat akademik program studi Manajemen.

5. Terima kasih yang tak terhingga untuk semua dosen-dosen yang telah memberikan pendidikan ilmu yang bermanfaat kepada penulis sehingga penulis bisa menyelesaikan studi ini dengan baik, dan terima kasih untuk seluruh staff, karyawan dan karyawati AKBP STIE "KBP" Padang.

6. Semua pihak yang telah banyak membantu yang tidak bisa penulis sebutkan satu persatu. 


\section{DAFTAR PUSTAKA}

Amri, D. (2011). Pengaruh Kepuasan Atas Kualitas Produk Terhadap Loyalitas Pengguna Blackberry Di Kota Padang. Ekonomi Dan Bisnis, 1-11.

Anggraeni, A. D., \& Annisawati, A. A. (2017). Forum Keuangan dan Bisnis Indonesia ( FKBI ) When Fintech Meets Accounting: Opportunity and Risk Pengaruh Kualitas Pelayanan Terhadap Kepuasan Pada Mahasiswa Program Studi Manajemen Bisnis Poltekpos Saat ini di Indonesia Perguruan Tinggi terhadap Kepuasa. Forum Keuangan dan Bisnis Indonesia (FKBI), 301-312.

Aryani, D., \& Rosinta, F. (2010). Pengaruh Kualitas Layanan terhadap Kepuasan Pelanggan dalam Membentuk Loyalitas Pelanggan. Jurnal Ilmu Administrasi Dan Organisasi, 17(2), 114-126.

Aziz, N. (2019). Pengaruh Kualitas Layanan Terhadap Kepuasan Nasabah SMS Banking Pada Bank Nagari Cabang Pembantu RSUP DR M Djamil Padang. https://doi.org/10.17605/OSF.IO/S3JVG

Dewi, N. K., Andri, G., \& Yonaldi, S. (2012). Pengaruh Iklan, Citra Merek, Dan Kepuasan Konsumen Terhadap Loyalitas Konsumen Dalam Menggunakan Vaseline Hand and Body Lotion Di Kota Padang ( Studi Kasus Di Pt. Unilever Cabang Padang ). Jurnal Manajemen Dan Kewirausahaan, 3(2), $11-29$.

Fernandes, Y. D., \& Marlius, D. (2018). Peranan Customer Service Dalam Meningkatkan Pelayanan Kepada Nasabah Pada PT. Bank Pembangunan Daerah Sumatera Barat Cabang Utama Padang. https://doi.org/10.31227/osf.io/wrh3p

Fernos, J., \& Putra, Y. E. (2019). Analisa Pengaruh Kualitas Pelayanan Terhadap Kepuasan Nasabah Pada PT. Bank Mega Syari'ah Padang. https://doi.org/10.31219/osf.io/y2baf

Haryanto, R. A. (2013). Strategi Promosi, Kualitas Produk, Kualitas Layanan Terhadap Kepuasan Pelanggan Pada Restoran Mcdonald'S Manado. Journal of Chemical Information and Modeling, 1(4), 1465-1473. https://doi.org/10.1017/CBO9781107415324.004

Indriani, F. (2015). Pelanggan Pada Papandayan English Conversation. Wacana Ekonomi Universitas Garut, 13(3), 10-16.

Ketut Gunawan, \& S. Pantja Djati. (2011). Kualitas Layanan dan Loyalitas Pasien (Studi pada Rumah Sakit Umum Swasta di Kota Singaraja-Bali). Jurnal Manajemen Dan Kewirausahaan, 13(1), 32-39. https://doi.org/10.9744/jmk.13.1.32-39 
Marcell, \& Adiwijaya, M. (2017). Pengaruh Dimensi Kualitas Layanan Terhadap Loyalitas Pelanggan di Auto Bridal Surabaya. Agora Vol.5, No. 1, (2017), $5(1)$.

Marlius, D. (2018). Loyalitas Nasabah Bank Nagari Syariah Cabang Bukittinggi Dilihat Dari Kualitas Pelayanan. Jurnal Pundi. Volume 1. No. 3. Hal.12-22. https://doi.org/10.31575/jp.v1 i3.60

Marlius, D. (2018). Pengaruh Dimensi Kualitas Pelayanan Website Akademik Terhadap Kepuasan Mahasiswa Pada STIE "KBP”. Jurnal Ipteks Terapan. Volume 12. No. 2. Hal. 116-128. http://doi.org/10.22216/jit.2018.v12i2.633

Natalia, S. (2010). Pengaruh citra merek, kualitas produk dan kualitas pelayanan terhadap loyalitas pelanggan melalui kepuasan pelanggan pada marcelio speed shop. Manajemen Bisnis.

Nurdianto, D., \& Yuniati, T. (2013). Pengaruh Kualitas Produk dan Citra Sebagai Variabel Intervening Terhadap Keputusan Konsumen Dalam Membeli Motor Honda. Jurnal Ilmu Dan Riset Manajemen, 2(10).

Purba, R. P. (2017). Pengaruh Citra Perusahaan Terhadap Loyalitas Pelanggan (Studi Kasus PT. Bintang Utara Perwakilan Dolok Sanggul). Jom Fisip, 4(2), $1-15$.

Putra, G. B. S., Kumadji, S., \& Hidayat, K. (2015). Keputusan Berkunjung ( Survei pada Pengunjung Taman Rekreasi PT . Selecta , Kota Batu , Jawa Timur ). Administrasi Bisnis, 26(2), 1-8.

Putra, Y. E., \& Aziz, N. (2019). Pengaruh Kualitas Pelayanan Dan Kepuasan Pelanggan Terhadap Loyalitas Nasabah PT. Bank Rakyat Indonesia Cabang Padang. https//doi.org/10.31219/osf.io/hcsw2

Qomariah, N. (2012). Pengaruh Kualitas Layanan dan Citra Institusi terhadap Kepuasan dan Loyalitas.

Ramadhan, A. G., \& Laily, N. (2016). Pengaruh Kualitas Pelayanan, Citra Dan Kepuasan Pelanggan Terhadap Loyalitas Pelanggan. Ilmu Dan Riset Manajemen, 5(September), 1-15.

Safitri, R. N., \& Marlius, D. (2017). Penerapan E-Banking Dalam Meningkatkan Jasa Dan Layanan Perbankan Di PT. Bank Rakyat Indonesia Cabang Padang. https://doi.org/10.31227/osf.io/gk v8t

Tiza, M. F., \& Susanti, F. (2019). Pengaruh Kualitas Pelayanan Terhadap Kepuasan Pelanggan, Studi kasus pada perusahaan JNE Cabang Padang. https://doi.org/10.31227/osf.io/hx87m 
Ulfa, M., \& Mayliza, R. (2019). Pengaruh Kualitas Pelayanan Dan Kepuasan Pelanggan Terhadap Loyalitas Pelanggan PDAM Kota Padang. https://doi.org/10.31219/osf.io/spmgv 